\title{
COMPARISON OF FRUCTOSAMINE AND ALPHA-1-ANTITRYPSIN IN PATIENTS WITH DIABETIC RETINOPATHY
}

\author{
Nankova D. ${ }^{1}$, M. Mihaylova ${ }^{1}$, I. Tzinlikov ${ }^{2}$, V. Mihaylov ${ }^{3}$ \\ ${ }^{1}$ Department of Chemistry, Biochemistry, Physics and Biophysics, ${ }^{2}$ Department of Internal Diseases, \\ ${ }^{3}$ Department of Pediatrics, Medical University of Pleven
}

\begin{abstract}
The role of alpha-1-antitrypsin (A1AT), serine protease inhibitor, in diabetic retinopathy is not exactly defined yet. The major pathogenic factor of diabetic microangiopathy is the non-enzymatic protein glycosylation. Chronically elevated serum glucose levels can disturb the structure and function of vascular matrix proteins by cross-linking rearrangement and cause narrowing of the luminal diameter of the microvessels in the retina, $i$. e. diabetic retinopathy. Fructosamine test is considered clinically useful for assessing the short-term integrated blood glucose control in the previous one to three weeks. It is based on the alkaline reducing activity of non-enzymatic glycated serum proteins as selected according to their biological half-lives and relative concentrations, e.g. albumin, IgA, apolipoproteins, haptoglobin, transferrin, alpha-2-macroglobulin and A1AT. The aim of this study was to estimate the comparison between the serum fructosamine levels and A1AT in diabetic retinopathy patients. It covered 18 patients aged between 38 and 66 years and hospitalized in the Department of Internal Diseases, Medical University of Pleven, and 20 healthy subjects. Examinations of A1AT were done after the method of rocket immunoelectrophoresis. Fructosamine was measured after Johnson colorimetric method (Roche test fructosamine). Serum A1AT levels were significantly decreased in 11 patients $(61,1 \%)$ and increased in 6 ones $(33,3 \%)$ as there was no difference in one patient $(5,5 \%)$ when compared to the control group. Serum fructosamine levels were significantly increased in 10 patients $(55,5 \%)$ and reduced in two ones $(11,1 \%)$ as there was no difference between these levels and the reference ones in 5 patients $(27,7 \%)$. The statistical analysis showed a significant correlation $(p<0,005)$ between the elevated serum fructosamine levels and the decreased A1AT ones in diabetic retinopathy patients. The non-enzymatic protein glycosylation manifested by the elevated fructosamine level corresponds with the increased proteolytic activity of the enzymes, i.e. A1AT deficiency as a pathogenic factor for the development of diabetic retinopathy.
\end{abstract}

Key words: alpha-1-antitrypsin, fructosamine, diabetic retinopathy, rocket immunoelectrophoresis, blood glucose control

\section{INTRODUCTION}

The pathogenesis of diabetic microangiopathy includes several biochemical processes (13-15) and the non-enzymatic protein glycation is its major pathogenic factor. Chronically elevated serum glucose levels can disturb the structure and function of vascular matrix proteins by cross-linking rearrangement $(8,17)$ and cause narrowing of the luminal diameter of the microvessels in the retina, i. e. diabetic retinopathy (4). When blood glucose levels are elevated during a period of time, the glucose molecules permanently bind with proteins within a process called glycation. The frustosamine is formed when the carbonyl group of glucose reacts with an amino group of the

\footnotetext{
Address for correspondence:

M. Mihaylova, Dept. of Chemistry, Biochemistry, Physics and Biophysics, Medical University of Pleven

1 Sv. Kliment Ohrdski Str., Pleven 5800, Bulgaria

e-mail:mmilka@abv.bg
}

polypeptide chain. Glycated serum proteins and haemoglobin will remain bound with glucose for the life of the protein and, therefore, provides a record of average blood glucose in a time period. Red blood cells have a life-span of 120 days, thus glycated haemoglobin (HbA1C) represents an average blood glucose during the past 2-3 months. Serum proteins have a shorter life-span of 14-21 days, thus glycated serum proteins (GSP) or fructosamine reflect the average glucose levels for a 2-3-week period. Effective management of diabetes aims at keeping the blood glucose levels as close to normal as possible in order to avoid complications and progressive damage associated with elevated glucose levels.

The fructosamine test is considered clinically useful for assessing the short-term integrated blood glucose control in the previous one to three weeks. It is based on the alkaline reducing activity of non-enzymatic glycated serum proteins as selected according to their biological half-lives and relative concentrations such as albumin, IgA, apolipoproteins, 
haptoglobin, transferrin, alpha-2-macroglobulin and alpha-1-antitrypsin (A1TA) (3,7).

The role of A1AT, a serine-protease-inhibitor, in diabetic retinopathy is not exactly defined yet. The proteinases of neutrophils can cause serious tissue damage such as hydrolysis of elastin, collagens and other proteins in the extracellular matrix, if their actions are not checked. Most proteinases are lysosomal enzymes and exist mainly as inactive precursors in normal neutrophils. A few of these enzymes are released into normal tissues, with the amount increasing markedly during inflammation. The activities of proteinases are normally controlled by a number of antiproteinases present in the plasma and the extracellular fluid (18). In addition, A1AT can be hydrolyzed by activated collagenase and gelatinase. The overall balance of proteinase- antiproteinase action can be altered by late diabetic complications $(14,17)$, in the context of dysfunction of microvessel permeability, i. e. according to the hypothesis of proteinase-antiproteinase disbalance $(15,16)$.

The aim of this study was to estimate the comparison between the serum fructosamine levels and A1AT in diabetic retinopathy patients.

\section{MATERIAL AND METHODS}

It covered 18 patients aged between 38 and 66 years and hospitalized in the Department of Internal Diseases, Medical University of Pleven, and 20 healthy subjects. Examinations of A1AT were done after the method of rocket immunoelectrophoresis (RIE) after Axelsen $(1,6)$ and Dimitrova (2). The apparatus for RIE was our own construction. TEC-3M was used as a source of electricity. Agarose (MERCK, Sevac), Antibody (Sevac), veronal buffer with $\mathrm{pH}$ of 8,6 (Merck), and Standard (Sevac) are used. Antibody-containing agarose gels of uniform thickness were prepared. After appropriate dilution, the samples of $5 \mu \mathrm{L}$ were deposited in the wells. Standard samples in suitable dilutions were deposited in the middle holes of the row. The glass plate was transferred to the electrophoresis apparatus as soon as the samples had been applied. A power supply was connected and up to $20 \mathrm{volt} / \mathrm{cm}$ could be applied if the electrophoresis apparatus had a cooling system. The precipitation peaks were ready to be measured directly, however, the gel should preferably be dried and stained to facilitate evaluation of peak heights. The glass plates were placed on a graph paper and peak heights from the centre of the wells to the top of the peaks were measured under magnifying glass.

Fructosamine was estimated after Johnson colorimetric method (Roche test fructosamine) (7). In alkaline medium, fructosamine in its ketoaminic form reduced nitroblue tetrazolium (NBT) to formazan by temperature at $370 \mathrm{C}$. The rate of this reaction as determined by measuring the absorbance at $530 \mathrm{~nm}$ was directly proportional to fructosamine concentration in the sample.

\section{RESULTS}

Serum A1AT levels were significantly decreased in 11 patients $(61,1 \%)$ and increased in 6 ones $(33,3 \%)$ as there was no difference in one patient $(5,5 \%)$ when compared to the control group (Table 1 and Table 2 and Fig. 1 and Fig. 2).

Table1. Serum A1AT and fructosamine levels in diabetic retinopathy patients

\begin{tabular}{|c|c|c|c|c|c|}
\hline No & $\begin{array}{l}\text { Patient's } \\
\text { initials }\end{array}$ & Sex & Age & $\begin{array}{c}\text { fructosamine } \\
(\mu \mathrm{mol} / \mathrm{L})\end{array}$ & $\begin{array}{c}\text { A1AT } \\
(\mathbf{m g} \%)\end{array}$ \\
\hline 1. & P.B. & $\mathrm{M}$ & 64 & 4,49 & 144 \\
\hline 2. & K.G. & $\mathrm{F}$ & 58 & 6,46 & 240 \\
\hline 3. & G.I. & $\mathrm{F}$ & 48 & 5,95 & 420 \\
\hline 4. & P.M & $\mathrm{M}$ & 62 & 2,9 & 264 \\
\hline 5. & V.B. & $\mathrm{M}$ & 53 & 0,649 & 336 \\
\hline 6. & I.S. & M & 49 & 0,635 & 288 \\
\hline 7. & L.K. & $\mathrm{F}$ & 66 & 2,165 & 336 \\
\hline 8. & T.T. & $\mathrm{F}$ & 64 & 1,335 & 252 \\
\hline 9. & M.O. & M & 60 & 1,177 & 270 \\
\hline 10. & S.P. & $\mathrm{M}$ & 51 & 5,56 & 301 \\
\hline 11. & H.I. & $\mathrm{F}$ & 38 & 2,78 & 288 \\
\hline 12. & G.X. & $\mathrm{F}$ & 46 & 3,12 & 384 \\
\hline 13. & A.A. & M & 62 & 2,22 & 240 \\
\hline 14. & A.G. & $\mathrm{F}$ & 75 & 1,24 & 336 \\
\hline 15. & A.I. & $\mathrm{F}$ & 77 & 1,87 & 288 \\
\hline 16. & A.P. & $\mathrm{M}$ & 80 & 1,45 & 264 \\
\hline 17. & S.D. & $\mathrm{F}$ & 70 & 1,67 & 420 \\
\hline 18. & P.D. & $\mathrm{F}$ & 61 & 2,34 & 270 \\
\hline
\end{tabular}

Serum fructosamine levels were significantly increased in 10 patients $(55,5 \%)$ and reduced in two ones $(11,1 \%)$ as there was no difference between these levels and the refer-

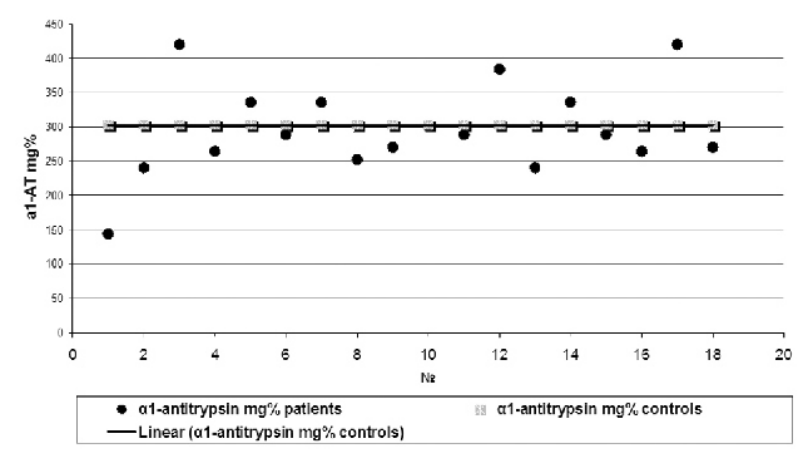

Fig. 1. Correlation between the serum A1AT levels in diabetic retinopathy patients and in controls 


\begin{tabular}{||l|c|c|c|c|c|c|c|c|c|c|c|c|c|c|c|c|c|c|c|c||}
\hline \hline No & 1 & 2 & 3 & 4 & 5 & 6 & 7 & 8 & 9 & 10 & 11 & 12 & 13 & 14 & 15 & 16 & 17 & 18 & 19 & 20 \\
\hline A1AT (mg \%) & 325 & 325 & 325 & 325 & 325 & 440 & 310 & 270 & 300 & 325 & 275 & 240 & 350 & 300 & 260 & 260 & 275 & 290 & 280 & 260 \\
\hline
\end{tabular}

\section{REFERENCES}

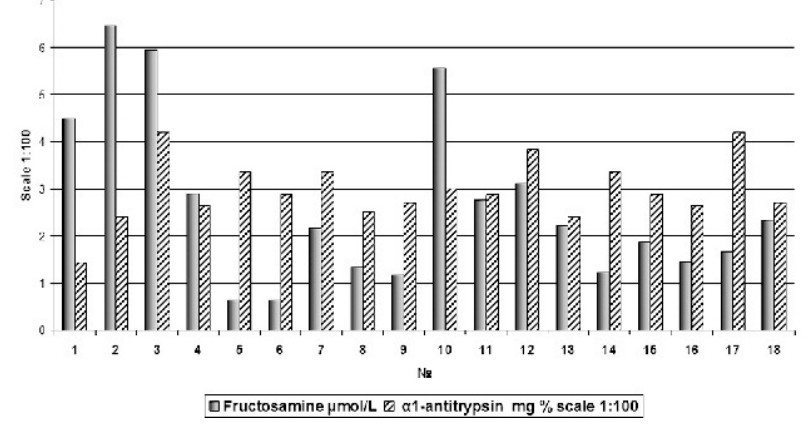

Fig. 2. Correlation between the serum levels of A1AT and fructosamine in diabetic retinopathy patients

ence ones in 5 patients $(27,7 \%)(0,96-1,56 \mu \mathrm{mol} / \mathrm{L})$. The statistical analysis showed a significant correlation $(p<0,005)$ between the elevated serum fructosamine levels and the decreased A1AT ones in the patients with diabetic retinopathy.

\section{DISCUSSION}

The discussion about the elevated serum A1AT levels in the patients with late diabetic complications is, probably, in response to the 'acute phase reaction' mechanism during the long-term hyperglycemic complication $(5,10)$. The increased proteolytic activity (A1AT deficiency in $61,1 \%$ of diabetic retinopathy patients) correlates to the high levels of non-enzymatic glycosylated proteins in $55,5 \%$ of the cases in the proband group. These results correspond to the idea of the study that not only the non-enzymatic protein glycation but also the disbalance between proteinases and antiproteinases can contribute to the development of microvascular damage in diabetes mellitus patients (11). We therefore suggest that both non-enzymatic protein glycation and increased proteolytic activity, i.e. A1AT deficiency correspond with diabetic retinopathy and the most commonly discrepant correlation of fructosamine and A1AT in diabetic retinopathy patients.

\section{CONCLUSSION}

The non-enzymatic protein glycosylation manifested by the elevated fructosamine level corresponds with the increased proteolytic activity of the enzymes, i.e. A1AT deficiency as a pathogenic factor for the development of diabetic retinopathy.
1. Axelsen, N. H., J. Kroll, B. Beeke. A manual of quantitative immunoelectrophoresis. Methods and applications. Oslo Bergen Troms, Universitetsforlaget, 1990.

2. Dimitrova, D. N. Alpha-1-antitrypsin quantification method in serum and bronchoalveolar lavage. Copyright certificate No 3/April, 1990, issued by the Institute of Inventions and Innovations. Sofia.

3. Dosheva, I. Methodological problems of determination of glycated proteins. Medical University of Pleven, 1988, 14-15 (in Bulgarian).

4. Gao, G., C. Shao, S. X. Zhang, A. Dudley, J. Fant, J. X. Ma. Kallikrein-binding protein inhibitors, retinal neovascularization and decreases vascular leakage.- Diabetologia, 46, 2003, No 5, 689-698.

5. Guetier, J.-M., P. Gorden. Hypoglycaemia.Endocrinol. Metab. Clin. N. Am., 35, 2006, No 3, 181-189.

6. Gupta, P. K., J. K. Frost, S. Geddes, B. Aracil, F. Davidovski. Morphological identification of alpha-1-antitrypsin in pulmonary macrophages.- Hum. Pathol., 10, 1979, No 3, 345-347.

7. Johnson, R. N., P. A. Metcalf, J. R. Baker. Fructosamine: a new approach to the estimation of serum glycosylprotein. An index of diabetic control.Clin. Chim. Acta, 127, 1983, No 1, 87-95.

8. Katakami, N., M. Matsuhisa, H. Kaneto, T. A. Matsuoka, K. Sakamoto, Y. Nakatani, et al. Decreased endogenous secretory advanced glycation end product receptor in type 1 diabetic patients: its possible association with diabetic vascular complications.- Diabetes Care, 28, 2005, No 11, 2716-2721.

9. Laure11, C. B. Electroimmunoassay.- Scand. J. Clin. Lab. Invest., 29, 1972, Suppl. 124, 21-37.

10. Lee, S. Y., H. G. Lee, H.W. Chung, Y. H. Yoon, J. G. Kim. Efficacy of intravitreal triamcinolone acetonide for eyes with postvitrectomy diabetic vitreous hemorrhage.- J. Korean Ophtalmol., 21, 2007, No 4, 208-212.

11. Mostafa, M., N. Samy, M. Afifi, M. Hashem, A. Azeb. Evaluation of plasma endothelin-1 and serum inflammatory markers in patients with diabetic retinopathy.- J. Med. Sci., 5, 2005, No 1, 35-42.

12. Mancini, G., D. R. Nash, J. F. Heremans. Further studies on single radial immunodiffusion. 3. Qualitative analysis of related and unrelated antigens.- Immunochemistry, 7, 1970, No 3, 261-264. 
13. Marks, D. B., A. D. Marks, C. M. Smith. Nitrogen metabolism.- In: Basic medical biochemistry - a clinical approach. Stanford CT, Williams \& Wilkins, 1996, p. 664.

14. Murray, R. K., D. Granner. Plasma proteins, white blood cells.- In: Harper's biochemistry. $26^{\text {th }}$ ed. Stanford CT, 2003, 589-590, 623-624.

15. Petrunova, N., V. Genova, M. Baleva, K. Nikolov. The level of factor V-von Willebrand and its inhibitors in diabetic retinopathy.- Vutr. bolesti, 27, 1988, No 5, 46-50 (in Bulgarian).

16. Schmidt, A. M, S. D. Yan, J. Brett, R. Mora, R. Nowygrod, D. Stern. Regulation of human mononuclear phagocyte migration by cell sur- face-binding proteins for advanced glycation end products.- J. Clin. Invest., 91, 1993, No 5, 2155-2168.

17. Schmidt, A. M., O. Hori, J. X. Chen, J. F. Li, J. Crandall, J. Zhang, et al. Advanced glycation endproducts interacting with their endothelial receptor induce expression of vascular cell adhesion molecule-1 (VCAM-1) in cultured human endothelial cells and in mice. A potential mechanism for the accelerated vasculopathy of diabetes.- J. Clin. Invest., 96, 1995, No 3, 1395-1403.

18. Shimojo, N., S. Fujii, Y. Funae, M. Wada. Plasma inactive renin in patients with diabetes mellitus: effects of standing and the relation to serum protease inhibitor.- Endocrinol. Jpn., 30, 1983, No 2, 147-153. 